\title{
Development of methodological basics of internal control of stocks at the agricultural enterprise
}

\author{
Alsou Zakirova ${ }^{1, *}$, Guzaliya Klychova ${ }^{1}$, Ludmila Tarasova ${ }^{2}$, Nadezhda $_{\text {Pimenova }}{ }^{3}$, and \\ Olga Yu. Abasheva ${ }^{3}$ \\ ${ }^{1}$ Kazan State Agrarian University, 65, Karl Marx str., 420015, Kazan, Russia \\ ${ }^{2}$ Yanka Kupala State University of Grodno, 22, Ozheshko Str., 230023, Grodno, Republic of Belarus \\ ${ }^{3}$ Izhevsk State Agricultural Academy, 11, Studencheskaya str., 426069, Izhevsk, Russia
}

\begin{abstract}
Stocks are one of the key factors that ensure consistency and continuity of reproduction. In this regard, internal control of stocks is an essential element of enterprise management of the enterprise. The aim of the article is to improve the methodological support of internal control of stocks. The article establishes the peculiarities of internal control of availability and safety of stocks in the conditions of development of digital economy. In order to improve control procedures, working documents of internal control of availability and safety of Stocks were developed. In the course of the study, the main stages of internal control over the flow and efficiency of the use of Stocks have been considered. In order to comply with the principles of rationality, priority and consistency in the conduct of internal control, it was proposed to use a working document of internal control «Program for internal control of the movement and efficiency of Stock use». To verify the correctness of the assessment of Stocks during their receipt, procurement, purchase it is proposed to use a working document of internal control «Checking the correctness of the estimate of reserves when they arrive". This document allows you to identify errors in the evaluation of Stocks, the formation of their actual cost, which affects the cost of production and the final financial result. To increase informativeness and sufficiency of working documents at the analysis of movement of stocks we recommend to use working documents of the internal control containing planned (standard) indicators, similar data of the last periods, indicators on an accrual basis since the beginning of the controlled period. Comparing the controlled indicators with planned values it is possible to estimate their fulfillment and to find out the reasons of discrepancies that can appear as a result of thefts, abuses and violations.
\end{abstract}

\section{Introduction}

The need to form a system of economic security at the enterprise is due to the presence of a variety of threats and risks affecting the stability of the operation of the enterprise [1-

\footnotetext{
*Corresponding author: zakirovaar@mail.ru
} 
4]. In this regard, it is necessary to identify, assess, implement measures to prevent and minimize probable losses in the process of financial and economic activity $[5,6]$.

One of the elements of control and analytical support of enterprise management system is control and analytical support of risk reduction in the process of Stock management.

The economic security system of an enterprise is designed to prevent negative results of production and financial activities, using an effectively functioning system of internal control as the main tool [7-10]. With the help of basic methods of internal control, it is possible to identify and eliminate deficiencies in a timely manner to improve the economic efficiency of activities and improve the financial condition of the enterprise [11-13].

The main objective of internal control in the system of economic security is to timely inform the management personnel about changes in external and internal environment, for further management decisions, allowing to reduce financial losses, timely adapt the enterprise to the changes, preserve and rationally use resources of the enterprise, including Stocks [14-17]. To achieve this goal it is necessary to solve the following tasks:

1. To determine the compliance of the company's activities with the chosen development strategy, the degree of financial, economic and legal stability, the effectiveness of current production and financial activities;

2. To ensure the safety of material and financial resources available to the enterprise;

3. To maintain complete and accurate primary accounting and organize an effective accounting system for the facts of economic activities performed at the enterprise;

4. Provide observance by the employees of the enterprise of the requirements established by the legislation.

5. Rationally and economically use all kinds of resources;

6. To apply innovative technologies in the production process in order to increase productivity, reduce costs, improve financial and economic results of activities.

One of the necessary conditions for the effective functioning of organizations is Stock. They take a direct part in the production process, in the servicing of a large number of production cycles and fully transfer their value to the products produced, services rendered and work performed $[18,19]$.

The majority of production processes are carried out with their help; they also serve as the primary basis for the creation of the final product. Let us note that the development of an individual enterprise involves various changes in the production process and largely determines the nature of accounting and control of Stocks. They are one of the main conditions for reducing production costs, implementing the production program, and increasing competitiveness $[20,21]$. Objectivity and reliability of the information that is formed in the process of Stock accounting, affects the amount of value added tax, the financial result, taxable income, the amount of income tax. In this regard, internal control of Stocks is an essential element of the management of the enterprise and provides a stable and safe financial and economic activity $[22,23]$.

The information obtained as a result of internal control on the quantitative and qualitative state of Stocks, their cost estimate, allows management personnel to assess the financial condition, determine profitability and solvency, forecast and plan the activities of the enterprise, optimize the tax policy [24, 25].

An effectively organized system of internal control is a tool that contributes to the development of accounting activities, the reduction of intra-corporate and sectoral risks and, as a consequence, the economic security of the enterprise [26, 27].

Operations associated with the movement and use of Stocks, are operations with an increased level of risk due to the possible unauthorized write-off of Stocks, which leads to an artificial overestimation of the cost and, consequently, to a decrease in the tax base. Besides in the process of movement of stocks the great number of economic operations which are made out by a considerable quantity of primary registration documents is made. 
As a result there is a risk of writing off stocks without registration of justifying documents, the risk of not filling in some requisites in the documents.

In order to assess the risks discussed above, internal controls should check:

- how storage facilities are organized, whether the issuance and removal of stock is monitored, whether the storage sites are equipped with fire and security alarms;

- whether the fundamental principles of stock-taking were observed and whether the results of stock-taking were properly documented;

- whether primary documents are used to document business operations on the movement of inventory;

- the timeliness and completeness of primary documents,

- timeliness and completeness of the reflection of operations on inventory movement in the accounting registers;

- observation of standards and norms of inventory consumption;

- whether the accounting methods reflected in the accounting policy correspond to the current legislation; whether the methods accepted in the accounting policy are observed in the practical activities of the economic services;

- whether in the course of industrial and financial activity atypical operations on movement of stocks are made.

In economic literature various techniques of internal control in system of management of stocks of the enterprise are considered. At the same time, these methods can be refined taking into account modern tools to improve the enterprise management system.

\section{Materials and Methods}

The purpose of the internal control of stocks is to confirm the reliability of information about their availability and movement, to establish the compliance of the execution of operations on them with the current legislation in order to timely prevent violations, theft and abuse and make effective management decisions to optimize the stock management system and ensure the economic security of the enterprise. The tasks to be solved in the course of internal control of supplies include:

- assessment of the organization of accounting for this section of the audit;

- studying the basic provisions of accounting policy concerning inventory accounting;

- studying the composition and availability of stock;

- examination of the conditions of inventory storage;

- confirmation of the correctness of stock valuation;

- verification of documented inventory movement;

- verification of stock consumption in accordance with the established standards;

- verification of the correctness of stock movement transactions reflected in the books;

- to evaluate the results of stock inspections performed at the enterprise.

The objects of internal control of stocks are shown in Figure 1. 


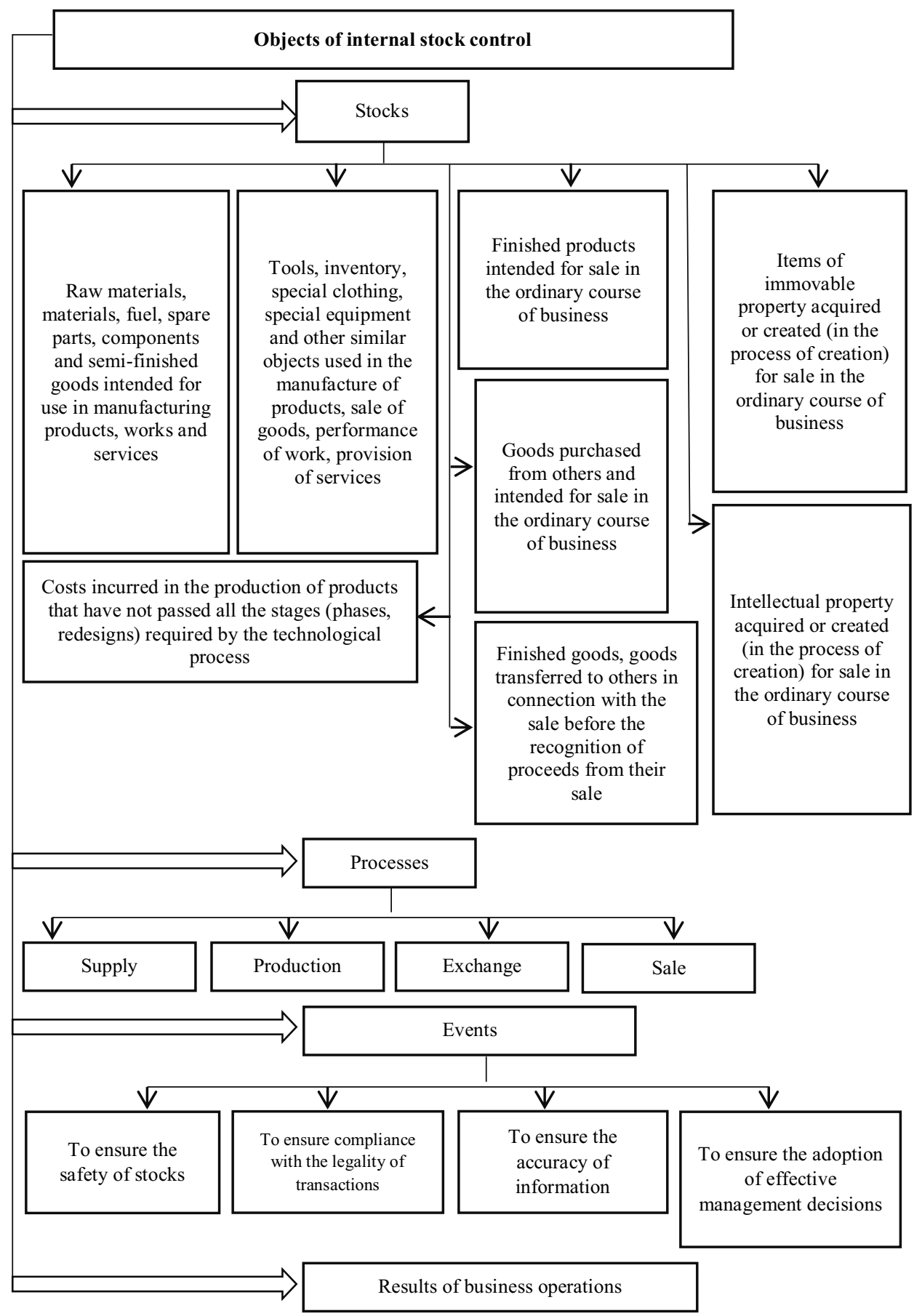

Fig. 1. Objects of internal control of stocks.

As it is visible from figure 1 objects of the internal control are represented by stocks, processes, the actions connected with movement of stocks, and also results of economic operations. 
Accepted in the theory and practice of division of control of stocks on industrial (control of operations on release in manufacture) and accounting (control of observance of principles of the accounting of movement of stocks) define directions of the internal control.

The main areas of internal inventory control include:

- evaluation of the inventory accounting system;

- verification of control over the availability and safety of inventory;

- verification of the correctness of the documentation and accounting of operations of receipt of inventories;

- verification of the correctness of the documentation and accounting of operations of withdrawal of inventories;

- analysis of the use of reserves;

- assessing the results of the audit and making recommendations.

The process of internal control of stocks movement provides for preliminary, current and final control.

At preliminary control internal structural divisions, using special control tools, check reliability of operations with stocks. At this stage it is established, whether the cost of inventories is correctly reflected at their receipt and disposal, as well as whether there are deviations from the established norms and standards.

With the current control carried out in the process of financial and economic activities, the process of accounting for stocks is monitored. The system of accounting registers, the system of reporting indicators, the correctness of the generalization of accounting data on the movement of stocks are subject to control.

Subsequent control checks the procedures for summarizing information on the movement of stocks at each stage of production. In addition, the completeness, reliability and objectivity of the formation of reporting indicators characterizing the operations of using stocks are checked.

The following stages of internal control of inventory transactions are distinguished:

1. Preparation and planning of internal control. At this stage, the system of accounting and internal control is studied and evaluated, the directions of control, the timing and performers of control procedures, the information and regulatory framework of the audit are determined;

2. Conducting internal control. This stage involves collecting evidence from external and internal sources, documenting the audit results in working documents of internal control;

3. The final stage. At this stage, the results of the audit are drawn up, recommendations are offered to eliminate the identified deficiencies and improve the efficiency of the enterprise.

With internal control of stocks, the following control methods can be applied (Figure 2). 


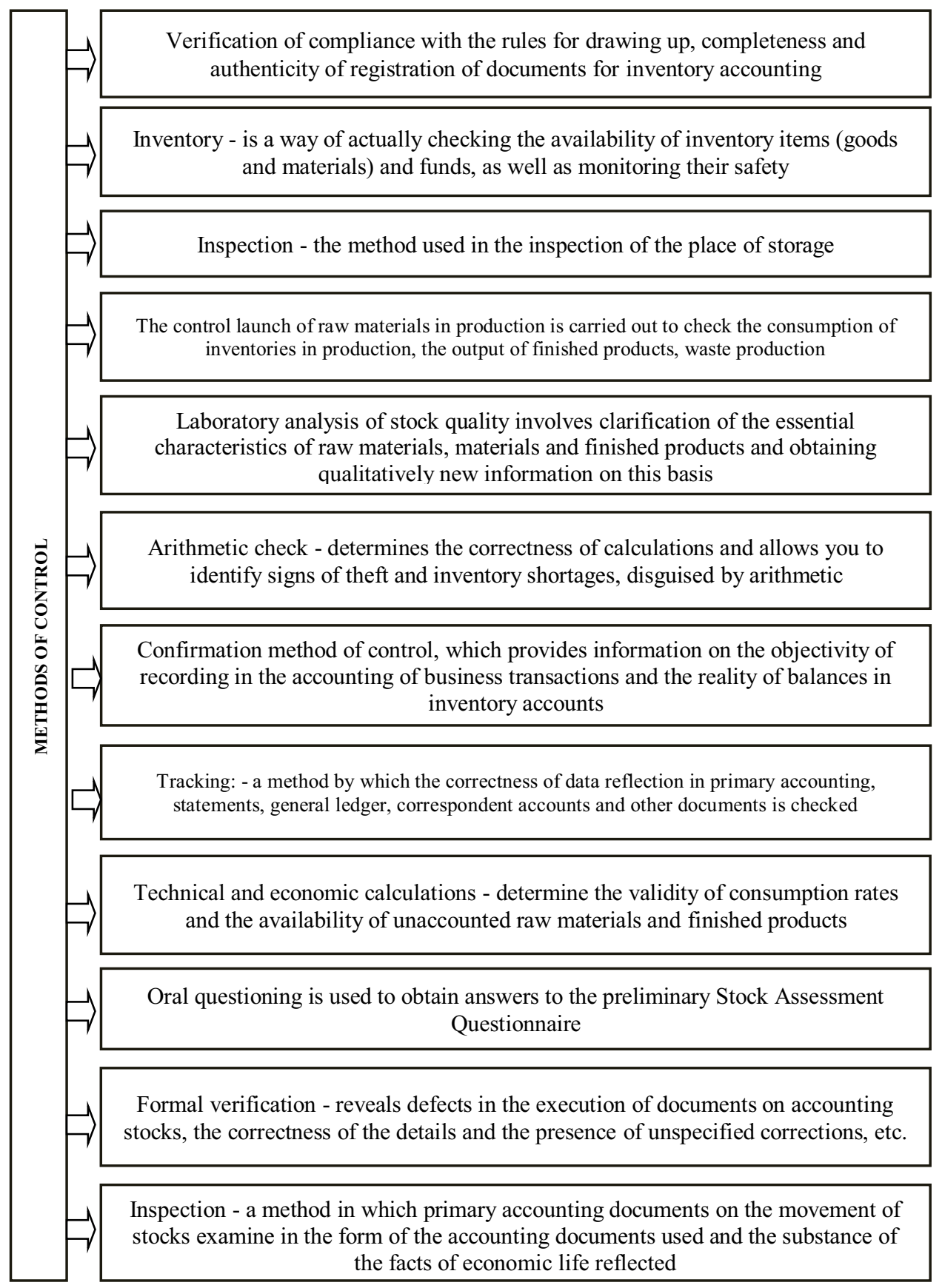

Fig. 2. Methods of internal inventory control.

At carrying out of check the basic attention should be given to release of stocks in manufacture, in this connection the basic method of the control is the control start of raw materials. With the help of this method the operations in which the norms and rates for the work performed are overstated, the production technology is violated are identified; the reasons for unreasonable writing-off of excessive losses and formation of unrecorded 
surplus raw materials are determined; the relevance and progressiveness of raw materials consumption rates per unit of production and waste rates are determined.

The quality of finished products is controlled by such a method as laboratory analysis. Laboratory analysis should be carried out in specialized, equipped laboratories. Laboratory analysis is a method that identifies the quality indicators of objects of control as a result of appropriate analysis (physical, chemical, biological analysis). Applying this method, it is possible to establish whether the quality indicators of stocks, which allows to ensure the safety and efficiency of the use of resources.

It is possible to verify objects in kind by organoleptic method, combining laboratory analysis and inventory. Inventory is a method that checks the availability of stock on a certain date by comparing the actual data with the accounting data [28]. This technique is used in internal control to ensure the safety of resources and information.

\section{Results}

In the conditions of development of the digital economy, the issues related to the control of inventory availability and safety using information technology are of particular relevance [29-32].

Firstly, the verification of access rights to computer programs is carried out. In particular, information support and security concerning the right of access to software is controlled. The list of persons who have the right of access to software is established; presence of local network and use of hardware and software for differentiation of access is defined. All this allows you to identify incorrectness in the allocation of access rights, and as a consequence of accidental or intentional distortion of data.

Secondly, it is necessary to check who and with what frequency information support is performed, and update used programs. You should find out whether there were failures in information systems in the reporting period, and what methods and means of protection are used at the enterprise to prevent such failures. Thus risks of errors occurrence due to incorrect program settings and usage of out-of-date software are detected.

Thirdly, it is necessary to evaluate the qualifications of employees of accounting services and materially responsible persons. It is necessary to determine, if any courses on professional retraining, advanced training and professional testing on knowledge and ability to use software products were conducted. This control procedure allows you to identify incorrect data entry and processing in the programs.

Fourth, it is necessary to check the frequency with which data are downloaded from the programs used in inventory accounting. It is also necessary to establish the circle of persons who are responsible for uploading data and the level of their competence. It should also be established whether the unloaded data was changed and corrected, whether the reconciliation was carried out at the end of the reporting period. Untimely uploading of data between programs may lead to its distortion and loss of information.

Organization and carrying out of internal control provides for evaluation of accounting system at the enterprise. Evaluation of the accounting system is the basis for planning internal control. The results of testing of accounting quality influence the definition of audit areas, types and sequence of control procedures and terms of their performance.

When organizing and performing internal control, it is necessary to assess the accounting system, its structure and industry peculiarities.

In order to obtain evidence of the effectiveness of accounting and analytical support for the acquisition, storage, write-off of inventories, we propose to use the internal control working document (ICWD) «Test for evaluating the accounting system» (Table 1). 
Table 1. Internal control working documents (ICWD) «Test for evaluating the inventory accounting system».

\begin{tabular}{|c|c|c|c|c|}
\hline \multirow{2}{*}{ Content of Question } & \multicolumn{4}{|c|}{ Content of Answer } \\
\hline & Yes & No & Partial & Note \\
\hline $\begin{array}{l}\text { 1. Are responsibilities and } \\
\text { authorities for the preparation of } \\
\text { primary documents and the } \\
\text { maintenance of synthetic and } \\
\text { analytical accounting } \\
\text { differentiated? }\end{array}$ & + & & & $\begin{array}{l}\text { Job descriptions defining the } \\
\text { duties and powers of employees } \\
\text { of the accounting service have } \\
\text { been developed }\end{array}$ \\
\hline $\begin{array}{l}\text { 2. Does the company develop an } \\
\text { accounting policy, including the } \\
\text { part regulating the accounting of } \\
\text { inventories? }\end{array}$ & + & & & $\begin{array}{l}\text { An accounting policy has been } \\
\text { developed and approved by the } \\
\text { head of the company. }\end{array}$ \\
\hline $\begin{array}{l}\text { 3. Are the provisions of the } \\
\text { accounting policy in terms of the } \\
\text { methods of writing off inventories, } \\
\text { the formation of registers for } \\
\text { recording the movement of } \\
\text { inventories, the use of a working } \\
\text { chart of accounts, etc. }\end{array}$ & + & & & $\begin{array}{l}\text { The accounting policy defines } \\
\text { the valuation option used in the } \\
\text { inventory accounting process. }\end{array}$ \\
\hline $\begin{array}{l}\text { 4. Has the accounting department } \\
\text { developed a document } \\
\text { management schedule? }\end{array}$ & + & & & $\begin{array}{l}\text { In the accounting department of } \\
\text { the company has developed a } \\
\text { schedule of documents, which } \\
\text { determines the departments that } \\
\text { must pass a document and its } \\
\text { executors, the period of its } \\
\text { presence in each of the } \\
\text { departments. }\end{array}$ \\
\hline $\begin{array}{l}\text { 5. Are there any deadlines for } \\
\text { documenting the movement of } \\
\text { inventory? }\end{array}$ & + & & & $\begin{array}{l}\text { The timing of the movement of } \\
\text { stocks is determined by the } \\
\text { workflow schedule }\end{array}$ \\
\hline $\begin{array}{l}\text { 6. Are the principles of timeliness, } \\
\text { completeness and legality of } \\
\text { inventory movement accounting } \\
\text { observed? }\end{array}$ & + & & & $\begin{array}{l}\text { The movement of stocks is } \\
\text { reflected in the accounting in a } \\
\text { timely manner, in full and in } \\
\text { accordance with regulatory } \\
\text { enactments. }\end{array}$ \\
\hline $\begin{array}{l}\text { 7. Do the facts of payment for } \\
\text { purchased stocks correlate with } \\
\text { the fact of their receipt and } \\
\text { crediting (the relationship of the } \\
\text { facts of activity is controlled)? }\end{array}$ & + & & & $\begin{array}{l}\text { Facts of payment for purchased } \\
\text { inventories correlate with the } \\
\text { fact of their receipt and receipt }\end{array}$ \\
\hline $\begin{array}{l}\text { 8. Is there a systematic } \\
\text { reconciliation of the data of } \\
\text { synthetic and analytical } \\
\text { accounting? }\end{array}$ & + & & & $\begin{array}{l}\text { Data of synthetic and analytical } \\
\text { accounting are reconciled at the } \\
\text { end of the reporting period }\end{array}$ \\
\hline $\begin{array}{l}\text { 9. Are the transactions agreed } \\
\text { upon, which confirm the } \\
\text { legitimacy of their performance? }\end{array}$ & & & + & $\begin{array}{l}\text { There are employee advance } \\
\text { reports on the purchase of } \\
\text { materials, that have not been } \\
\text { approved by his supervisor }\end{array}$ \\
\hline $\begin{array}{l}\text { 10. Is the movement and use of } \\
\text { stock being analyzed? }\end{array}$ & + & & & $\begin{array}{l}\text { Unused tangible assets and areas } \\
\text { of potential risk are identified, } \\
\text { material intensity, material } \\
\text { efficiency is evaluated }\end{array}$ \\
\hline $\begin{array}{l}\text { 11. Are the stocks classified into } \\
\text { appropriate groups for their }\end{array}$ & + & & & $\begin{array}{l}\text { Stocks are classified into } \\
\text { appropriate groups }\end{array}$ \\
\hline
\end{tabular}




\begin{tabular}{|l|l|l|l|l|}
\hline accounting? & & & & \\
\hline $\begin{array}{l}\text { 12. Are there contracts in place for } \\
\text { all supplies purchased from } \\
\text { suppliers? }\end{array}$ & & + & & $\begin{array}{l}\text { There are stocks for which there } \\
\text { are no contracts with suppliers. }\end{array}$ \\
\hline $\begin{array}{l}\text { 13. Does contractual obligations } \\
\text { fulfilled by stock suppliers? }\end{array}$ & + & & & $\begin{array}{l}\text { Contractual obligations are } \\
\text { fulfilled by stock suppliers }\end{array}$ \\
\hline $\begin{array}{l}\text { 14. Are stock movement reports } \\
\text { submitted to the accounting } \\
\text { department in compliance with } \\
\text { deadlines? }\end{array}$ & + & & & $\begin{array}{l}\text { deadlines for submitting reports } \\
\text { on the movement of stocks to } \\
\text { the accounting department are } \\
\text { respected }\end{array}$ \\
\hline $\begin{array}{l}\text { 15. Is inventory accounting } \\
\text { automated in the accounting } \\
\text { department of the company? }\end{array}$ & + & & & $\begin{array}{l}\text { The program 1C Accounting } 8.3 \\
\text { is used }\end{array}$ \\
\hline $\begin{array}{l}\text { 16. Does the program used in } \\
\text { inventory accounting in } \\
\text { accordance with applicable law? }\end{array}$ & + & & & $\begin{array}{l}\text { The program used in inventory } \\
\text { accounting complies with the } \\
\text { current legislation }\end{array}$ \\
\hline
\end{tabular}

The internal controller forms an opinion on the reliability of information on reserves, taking into account the factors presented in Table 2.

Table 2. Factors forming an opinion on the reliability of information on reserves.

\begin{tabular}{|c|c|c|c|}
\hline $\begin{array}{l}\text { Factors in forming an } \\
\text { opinion on the } \\
\text { reliability of stock } \\
\text { information }\end{array}$ & Threats & Causesofthreats & $\begin{array}{c}\text { Internal control } \\
\text { procedures for } \\
\text { identifying } \\
\text { threats }\end{array}$ \\
\hline $\begin{array}{l}\text { Completeness of } \\
\text { reflection on the } \\
\text { accounting accounts } \\
\text { and in the financial } \\
\text { statements of all stocks } \\
\text { belonging to the } \\
\text { economic entity. }\end{array}$ & $\begin{array}{l}\text { Incomplete } \\
\text { reflection of stocks } \\
\text { in accounting } \\
\text { accounts and in } \\
\text { financial statements } \\
\text { leads to an } \\
\text { underestimation of } \\
\text { reporting data }\end{array}$ & $\begin{array}{l}\text { Inventories that were } \\
\text { received from the } \\
\text { supplier and purchased } \\
\text { under the supply } \\
\text { agreement were not } \\
\text { reflected in the } \\
\text { accounting records, } \\
\text { since, according to the } \\
\text { agreement, the } \\
\text { inventories must be paid } \\
\text { after their sale, but the } \\
\text { ownership of these } \\
\text { inventories arose at the } \\
\text { time of their acceptance. }\end{array}$ & $\begin{array}{l}\text { Sampling from } \\
\text { primary } \\
\text { documents or } \\
\text { using } \\
\text { information of } \\
\text { an unrecorded } \\
\text { nature }\end{array}$ \\
\hline $\begin{array}{l}\text { Inappropriate increase } \\
\text { in stock balances and } \\
\text { turnovers }\end{array}$ & $\begin{array}{l}\text { The financial } \\
\text { performance of the } \\
\text { economic entity is } \\
\text { distorted. }\end{array}$ & $\begin{array}{l}\text { An economic entity } \\
\text { reflects in the balance } \\
\text { sheet reserves to which it } \\
\text { does not have ownership, } \\
\text { for example, received } \\
\text { under commission } \\
\text { agreements. }\end{array}$ & $\begin{array}{c}\text { Study of } \\
\text { contract and } \\
\text { accounting } \\
\text { records and their } \\
\text { comparison with } \\
\text { primary } \\
\text { documents } \\
\end{array}$ \\
\hline $\begin{array}{l}\text { The principle of } \\
\text { temporal certainty of } \\
\text { facts of economic life } \\
\text { is not observed. }\end{array}$ & $\begin{array}{l}\text { Incorrect distribution } \\
\text { of operations by } \\
\text { reporting periods }\end{array}$ & $\begin{array}{l}\text { Reflection in the } \\
\text { accounting of the } \\
\text { reserves received until } \\
\text { the transfer of ownership } \\
\text { of them }\end{array}$ & $\begin{array}{l}\text { Study and } \\
\text { accounting } \\
\text { records and } \\
\text { compare them } \\
\text { with primary } \\
\text { documents }\end{array}$ \\
\hline $\begin{array}{c}\text { Correctness of stock } \\
\text { valuation }\end{array}$ & $\begin{array}{l}\text { Incorrectly estimated } \\
\text { stocks }\end{array}$ & $\begin{array}{l}\text { The cost of purchased } \\
\text { (created) stock includes } \\
\text { the cost of storing stock. }\end{array}$ & $\begin{array}{l}\text { Determination } \\
\text { of elements } \\
\text { included in the } \\
\text { cost of stocks }\end{array}$ \\
\hline
\end{tabular}




\begin{tabular}{|c|c|c|c|}
\hline $\begin{array}{c}\text { Inaccuracy in the } \\
\text { classification of } \\
\text { The correctness of the } \\
\text { reflection of stocks on } \\
\text { of production stocks } \\
\text { the relevant accounts }\end{array}$ & $\begin{array}{c}\text { incorrectly } \\
\text { determined; } \\
\text { incorrect entry in the } \\
\text { accounting registers } \\
\text { of the inventory } \\
\text { results }\end{array}$ & $\begin{array}{c}\text { Assignment to stocks of } \\
\text { products, performance of } \\
\text { work, provision of } \\
\text { services }\end{array}$ & $\begin{array}{c}\text { Conducting } \\
\text { Inventory }\end{array}$ \\
\hline
\end{tabular}

As can be seen from the table 2 to the factors of forming an opinion on the reliability of the information about the stocks include:

1. Completeness of reflection on the accounts and in the accounting financial statements of all stocks belonging to the economic entity.

2. Unlawful increase of balances and turnovers of stocks;

3. Observance of the principle of temporal definiteness of the facts of economic life;

4. Correctness of an assessment of stocks;

5. Correctness of reflection of stocks on corresponding accounts of accounting.

At planning of the internal control the plan and the program are made. The recommended form of the internal control program of settlement operations is presented in Table 3.

Table 3. ICWD « Program for internal control of the movement and efficiency of Stock use».

\begin{tabular}{|c|c|c|c|c|c|c|}
\hline 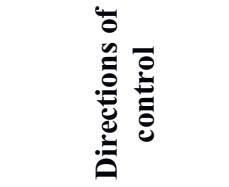 & 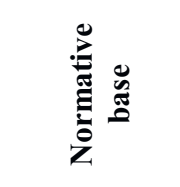 & 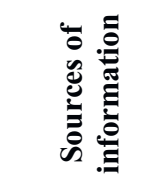 & & 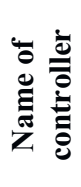 & 苍. & 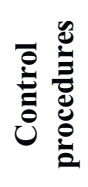 \\
\hline $\begin{array}{l}\text { 1. Evaluation of } \\
\text { the inventory } \\
\text { accounting } \\
\text { system; }\end{array}$ & $\begin{array}{c}\text { Federal Law } \\
\text { «On } \\
\text { Accounting», } \\
\text { Federal } \\
\text { accounting } \\
\text { standards } \\
\text { (FAS) } \\
5 / 2019 \\
\text { «Stocks» } \\
\end{array}$ & 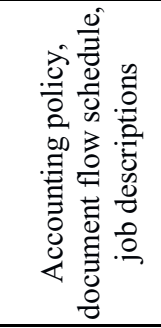 & 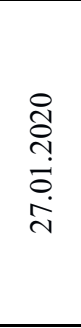 & $\begin{array}{l}0 \\
0 \\
0 \\
0 \\
0 \\
0 \\
0 \\
0\end{array}$ & $\begin{array}{l}\text { : } \\
\\
\circ\end{array}$ & 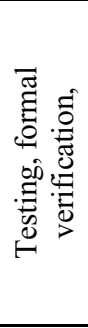 \\
\hline $\begin{array}{l}\text { 2. Verification of } \\
\text { ensuring control } \\
\text { over the } \\
\text { availability and } \\
\text { safety of stocks }\end{array}$ & $\begin{array}{c}\text { Methodical } \\
\text { instructions } \\
\text { on the } \\
\text { inventory of } \\
\text { property and } \\
\text { financial } \\
\text { liabilities. } \\
\text { Order of the } \\
\text { Ministry of } \\
\text { Finance of } \\
\text { the Russian } \\
\text { Federation of } \\
\text { 13.06.1995 г. } \\
\text { № } 49\end{array}$ & $\begin{array}{l}\text { Inventory } \\
\text { cards, } \\
\text { inventory } \\
\text { materials, } \\
\text { contracts of } \\
\text { materially } \\
\text { responsible } \\
\text { persons }\end{array}$ & $\begin{array}{l}\text { ते } \\
\text { ָे } \\
\dot{0} \\
\dot{\infty} \\
\text { ஸे }\end{array}$ & $\begin{array}{l}0 \\
0 \\
2 \\
0 \\
0 \\
0 \\
0\end{array}$ & $\begin{array}{l}\text { :0 } \\
\text { in }\end{array}$ & 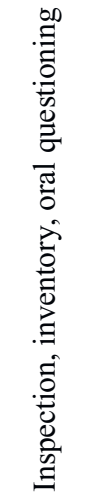 \\
\hline
\end{tabular}




\begin{tabular}{|c|c|c|c|c|c|c|}
\hline $\begin{array}{l}\text { 3. Verification of } \\
\text { the correctness of } \\
\text { the } \\
\text { documentation } \\
\text { and accounting } \\
\text { operations of the } \\
\text { receipt of stocks }\end{array}$ & $\begin{array}{c}\text { FAS 5/2019 } \\
\text { «Stocks», } \\
\text { Plan of } \\
\text { accounts for } \\
\text { financial and } \\
\text { economic } \\
\text { activities of } \\
\text { organizations } \\
\text { and } \\
\text { instructions } \\
\text { for its } \\
\text { application }\end{array}$ & $\begin{array}{l}\text { Contracts for } \\
\text { the supply of } \\
\text { stocks, bills } \\
\text { of lading, } \\
\text { invoices, } \\
\text { primary } \\
\text { documents } \\
\text { on receipt of } \\
\text { own } \\
\text { production } \\
\text { stocks, } \\
\text { registers of } \\
\text { synthetic and } \\
\text { analytical } \\
\text { accounting, } \\
\text { General } \\
\text { Ledger }\end{array}$ & 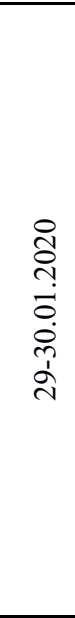 & $\begin{array}{l}0 \\
0 \\
0 \\
0 \\
0 \\
0 \\
0\end{array}$ & 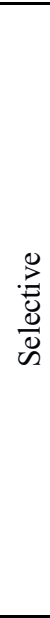 & 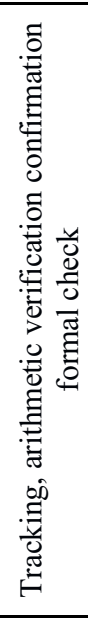 \\
\hline $\begin{array}{l}\text { 4. Checking the } \\
\text { correctness of } \\
\text { documenting and } \\
\text { accounting for } \\
\text { disposal of } \\
\text { inventories }\end{array}$ & $\begin{array}{c}\text { FAS 5/2019 } \\
\text { «Stocks», } \\
\text { Plan of } \\
\text { accounts for } \\
\text { financial and } \\
\text { economic } \\
\text { activities of } \\
\text { organizations } \\
\text { and } \\
\text { instructions } \\
\text { for its } \\
\text { application }\end{array}$ & $\begin{array}{c}\text { Consignment } \\
\text { notes, intra- } \\
\text { business } \\
\text { waybills, } \\
\text { limit and } \\
\text { intake cards, } \\
\text { registers of } \\
\text { synthetic and } \\
\text { analytical } \\
\text { accounting, } \\
\text { General } \\
\text { Ledger }\end{array}$ & 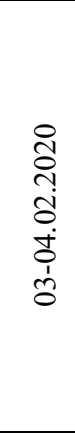 & $\begin{array}{l}0 \\
0 \\
0 \\
0 \\
0 \\
0 \\
0 \\
0\end{array}$ & $\frac{\stackrel{D}{0}}{\frac{\mathbb{d}}{\omega}}$ & 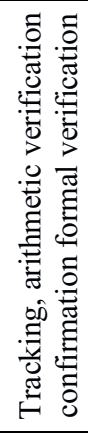 \\
\hline $\begin{array}{l}\text { 5. Analysis of } \\
\text { inventoryuse }\end{array}$ & $\begin{array}{c}\text { FAS } 5 / 2019 \\
\text { «Stocks», } \\
\text { Plan of } \\
\text { accounts for } \\
\text { financial and } \\
\text { economic } \\
\text { activities of } \\
\text { organizations } \\
\text { and } \\
\text { instructions } \\
\text { for its } \\
\text { application }\end{array}$ & $\begin{array}{l}\text { Warehouse } \\
\text { accounting } \\
\text { data on } \\
\text { receipts and } \\
\text { issues, } \\
\text { synthetic and } \\
\text { analytical } \\
\text { ledgers, } \\
\text { General } \\
\text { ledger, } \\
\text { accounting } \\
\text { (financial) } \\
\text { statements }\end{array}$ & 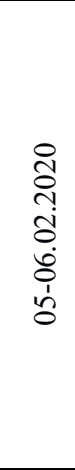 & $\begin{array}{l}0 \\
0 \\
0 \\
0 \\
0 \\
0 \\
0\end{array}$ & $\begin{array}{l}\text { To } \\
\text { D } \\
\text { \& }\end{array}$ & 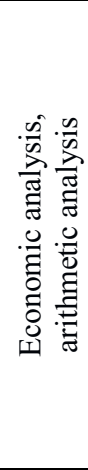 \\
\hline $\begin{array}{l}\text { 6. Evaluating the } \\
\text { results of the } \\
\text { inspection, } \\
\text { forming } \\
\text { recommendations }\end{array}$ & - & $\begin{array}{c}\text { Registers of } \\
\text { synthetic and } \\
\text { analytical } \\
\text { accounting, } \\
\text { General } \\
\text { Ledger }\end{array}$ & 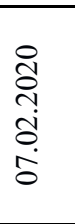 & $\begin{array}{l}0 \\
0 \\
0 \\
0 \\
0 \\
0 \\
0 \\
0\end{array}$ & 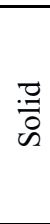 & \\
\hline
\end{tabular}

One of the directions of internal control of inventories is to check the organization of control over the availability and safety of stocks. A comprehensive study of this area of activity begins with a survey of places (warehouses, storage rooms, workshops) and storage conditions (sanitary standards, temperature regimes, humidity of the room air, correct storage); the state of fire safety and security of storage facilities; equipment of storage rooms with special equipment, devices, and machinery. 
It is checked how the material responsibility of workers responsible for the receipt, storage and release of stocks is organized. Persons responsible for material responsibility should carry out their activities on the basis of job descriptions, which determine their rights and obligations, the order and documentation of receipt and delivery of stock, the terms of reporting to the accounting department, etc.

To check the condition of storage and safety of stocks you can use the ICWP «Questionnaire for checking the condition of storage and safety of stocks» (Table 4).

Table 4. ICWD «Questionnaire for checking the condition of storage and safety of stocks».

\begin{tabular}{|c|c|c|c|}
\hline \multirow{2}{*}{ Contents } & \multicolumn{2}{|c|}{ Answers } & \multirow{2}{*}{ Note } \\
\hline & Yes & No & \\
\hline $\begin{array}{l}\text { 1. Whether the company's territory is } \\
\text { protected }\end{array}$ & + & & $\begin{array}{l}\text { The company's territory, including the } \\
\text { stock places, is guarded by a private } \\
\text { security company. }\end{array}$ \\
\hline $\begin{array}{l}\text { 2. Presence of fire and security alarm } \\
\text { system }\end{array}$ & + & & $\begin{array}{l}\text { Stock places are equipped with fire and } \\
\text { security alarm systems. }\end{array}$ \\
\hline $\begin{array}{l}\text { 3. Existence and correctness of material } \\
\text { liability agreements }\end{array}$ & & - & $\begin{array}{l}\text { Not all materially responsible persons } \\
\text { have properly executed material } \\
\text { liability agreements. }\end{array}$ \\
\hline $\begin{array}{l}\text { 4. Do the financially responsible } \\
\text { persons have the conditions to ensure } \\
\text { the safety of stocks (lockable storage } \\
\text { rooms, cabinets, safes, containers for } \\
\text { storing valuables) }\end{array}$ & + & & $\begin{array}{l}\text { Materially responsible persons have } \\
\text { the conditions to ensure the safety of } \\
\text { stocks. }\end{array}$ \\
\hline $\begin{array}{l}\text { 5. Are the storage areas equipped with } \\
\text { the necessary devices }\end{array}$ & + & & $\begin{array}{l}\text { Storage locations are equipped with the } \\
\text { necessary devices. }\end{array}$ \\
\hline $\begin{array}{l}\text { 6. Is the procedure for the removal of } \\
\text { stocks from the enterprise and the } \\
\text { issuance of powers of attorney for their } \\
\text { receipt controlled? }\end{array}$ & + & & $\begin{array}{l}\text { The company monitors the removal of } \\
\text { stock and the issuance of power of } \\
\text { attorney for its receipt. }\end{array}$ \\
\hline $\begin{array}{l}\text { 7. Is the actual availability and } \\
\text { condition of stocks controlled (physical } \\
\text { security, access restriction, inventory)? }\end{array}$ & + & & $\begin{array}{l}\text { The enterprise has organized physical } \\
\text { security and limited access to supplies. } \\
\text { Inventory is taken once a year before } \\
\text { annual reporting. }\end{array}$ \\
\hline $\begin{array}{l}\text { 8. Are the amounts of the balances on } \\
\text { the accounts of stocks being reconciled } \\
\text { with their actual balances in } \\
\text { warehouses? }\end{array}$ & + & & Yes, they are. \\
\hline $\begin{array}{l}\text { 9. Are there documents in the } \\
\text { warehouse that have not been } \\
\text { submitted to the accounting department } \\
\text { along with the reports? }\end{array}$ & & + & $\begin{array}{l}\text { All documents are submitted to the } \\
\text { accounting department along with the } \\
\text { reports. }\end{array}$ \\
\hline
\end{tabular}

Inspecting the places of storage of stocks on the documents available to the materially responsible persons, the controller checks the timeliness of registration of the movement of stocks and records in the registers of analytical accounting.

Inspecting the condition of the warehouse and checking the safety of stocks, followed by documentary control allows you to draw conclusions about the safety of stocks. The actual availability of stock is checked using such a method of actual control as an inventory check. The comptroller initiates and supervises the inventory. Prior to conducting an inventory, the controller requests documents reflecting the results of previous inventories; analyzes structural and quantitative changes in inventories; obtains about locations where inventories are stored; identifies high-value items and their accounting methods; and analyzes storage systems and documentation of stock movement. 
The presence of an internal controller is obligatory during an inventory, which is conducted before the preparation of the annual financial statements. In the case of an inventory on a certain interim date, the controller, by selectively reconciling the primary documents that take into account the movement of inventories, with accounting data, must establish the facts of receipt and disposal of inventories from the moment of the inventory to the reporting date.

Checking operations related to the procurement and acquisition of inventory in the internal control should follow the following sequence:

1. It is checked whether stocks are correctly classified according to such classification attributes as their functional role and purpose in the production process, economic content, structure, and the nature of ownership (Figure 3). As can be seen from Figure 3 incorrect classification of inventories leads to errors in the evaluation and correspondence of accounts, in the organization of analytical accounting;

2. Checking the validity of operations related to the receipt and procurement of stocks is based on the study of contracts with suppliers and primary documents that record these operations. Primary documents are analyzed in two directions: settlement and payment documents confirming the receipt of stocks from suppliers and documents that take into account the receipt of stocks of own production;

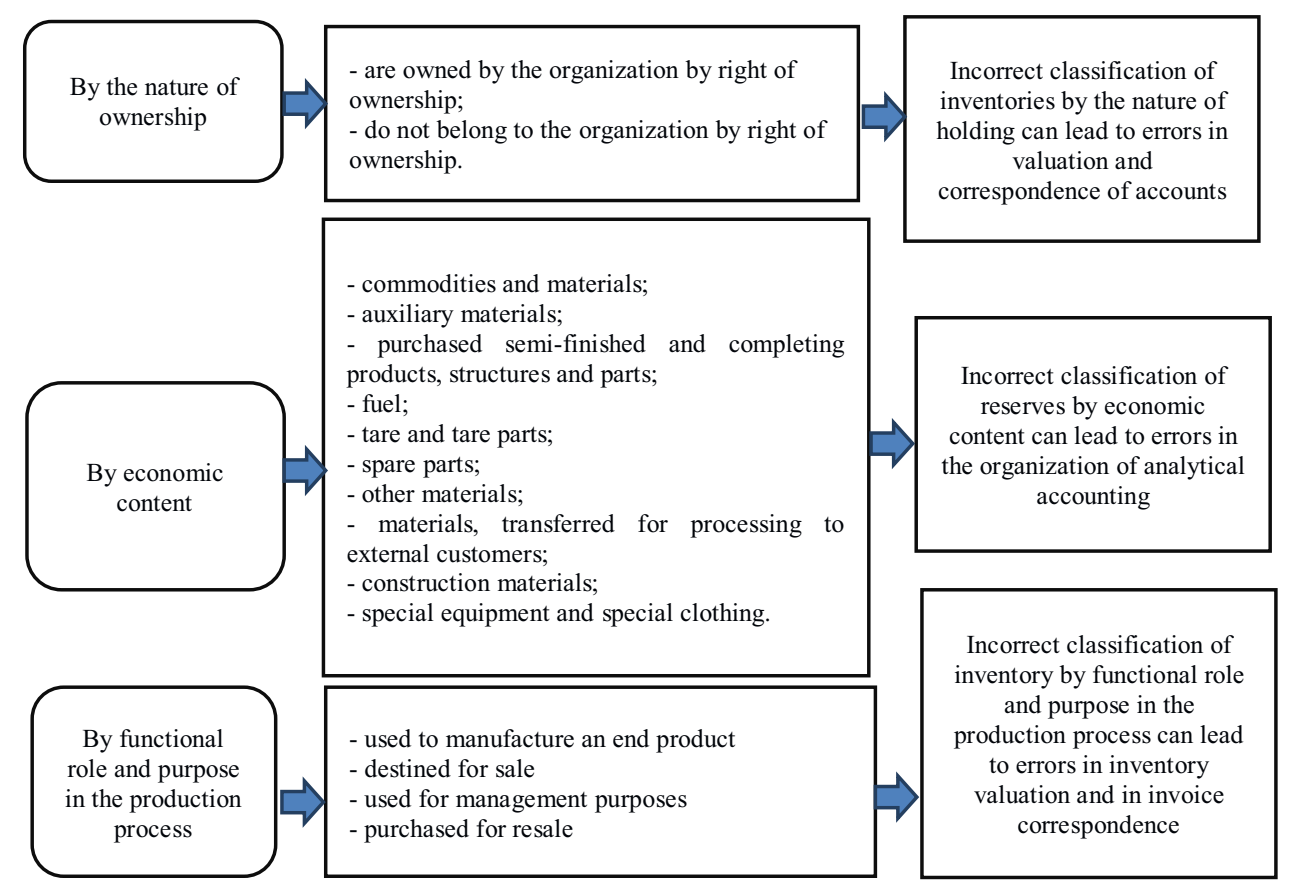

Fig. 3. Checking the correctness of stock classification.

3. Checking the completeness of receipt of purchased inventory controller needs to establish whether the total amounts in the inventory record sheets, the data in other accounting registers. To determine the amount of received stock and the correctness of the documentary registration of entering of goods it is necessary to compare the paid payment documents from suppliers with the receipt documents in warehouses and records in the card stock records.

Checking the completeness of the capitalization of stocks should be carried out taking into account the conditions and forms of settlements with suppliers, as well as taking into account the selected evaluation option. 
4. At internal control it is necessary to check the correctness of an assessment of stocks at their receipt, preparation, purchase. For this purpose it is established whether the cost of inventories is formed correctly, and whether the assessment of inventories corresponds to the current legislation. The order of check and control procedures applied depend on the directions of receipt of stocks. The results of the control procedures we suggest to reflect in the following working document of internal control (table 5).

Table 5. ICWD «Checking the correctness of the estimate of reserves when they arrive».

\begin{tabular}{|c|c|c|c|c|c|c|c|}
\hline 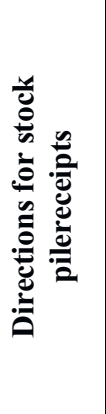 & 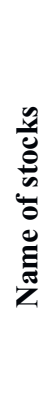 & 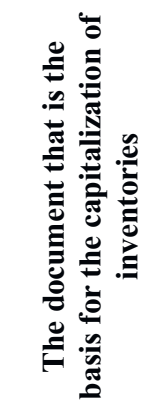 & 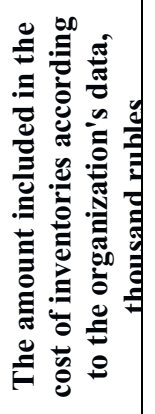 & 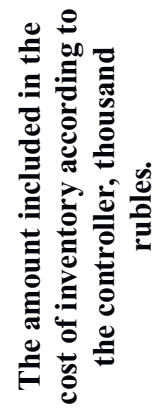 & 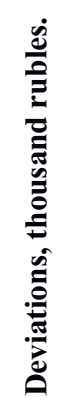 & 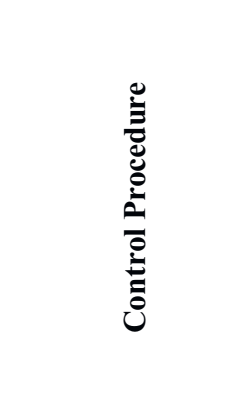 & $\frac{0}{8}$ \\
\hline \multirow{2}{*}{ 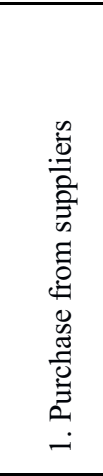 } & 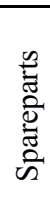 & $\begin{array}{l}\text { Invoice, } \\
\text { supply } \\
\text { agreement, } \\
\text { delivery } \\
\text { note }\end{array}$ & 448 & 448 & - & $\begin{array}{l}\text { Matching the } \\
\text { Identity } \\
\text { Suppliers' of and } \\
\text { Contractors' } \\
\text { Documents to } \\
\text { Accounting Data }\end{array}$ & - \\
\hline & $\begin{array}{l}\vec{D} \\
\Phi \\
\Phi\end{array}$ & $\begin{array}{l}\text { Invoice, } \\
\text { supply } \\
\text { agreement, } \\
\text { delivery } \\
\text { note }\end{array}$ & 281 & 291 & $\begin{array}{c}- \\
10\end{array}$ & $\begin{array}{l}\text { Comparison of } \\
\text { the identity of } \\
\text { supplier } \\
\text { documents data } \\
\text { with accounting } \\
\text { data }\end{array}$ & $\begin{array}{l}\text { The cost of } \\
\text { feed does not } \\
\text { include the } \\
\text { cost of } \\
\text { transportation } \\
\text { to the place } \\
\text { of storage. }\end{array}$ \\
\hline 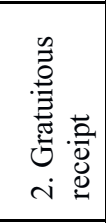 & 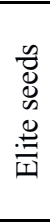 & $\begin{array}{c}\text { Contract } \\
\text { of } \\
\text { gratuitous } \\
\text { nature }\end{array}$ & 60 & 60 & - & $\begin{array}{l}\text { Checking the } \\
\text { correctness of } \\
\text { determining the } \\
\text { value of seeds } \\
\text { received under } \\
\text { the gift contract }\end{array}$ & - \\
\hline 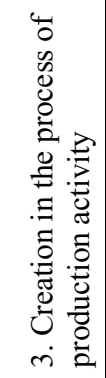 & $\ddot{\bar{z}}$ & $\begin{array}{l}\text { Milk } \\
\text { production } \\
\quad \text { diary, } \\
\text { production } \\
\text { report }\end{array}$ & 112 & 112 & - & $\begin{array}{l}\text { Arithmetic } \\
\text { check, check of } \\
\text { correctness of } \\
\text { correspondence } \\
\text { of accounts }\end{array}$ & - \\
\hline
\end{tabular}

Checking the correctness of the formation of the cost of inventories purchased from suppliers, compares the identity of the data contained in the documents of suppliers with accounting data. When checking operations to receive stocks against a contribution to the authorized capital or free of charge, the constituent documents, gratuitous agreements, 
constituent documents, accounting registers are examined, the correctness of determining the value of stocks is controlled.

When controlling the value of inventories that are created in the course of production activities, the form and content of operations reflected in the primary documents are checked, the accuracy and legality of the posting of inventories is confirmed, and the correctness of the correspondence of accounts is established.

5. The correctness of the correspondence of accounts is checked, cases are revealed when the received material values are not capitalized, but referred to other accounts (for accounting for costs, settlements, reserves, etc.).

Internal control of stock withdrawal for production and other areas begins with the assessment of the state of primary accounting.

When checking documents on the expenditure of inventories and their movement within the enterprise are used such methods of control, as a formal check, normative check, logical check, inspection, which allow to assess the accuracy of registration and accounting documents in the accounting department.

With a thorough check of the documents revealed facts of release of stocks without prior measurement, weighing, recalculations. Because as a result of this there are hidden from the accounting inventory surplus.

It should be determined whether the current consumption standards are complied with, whether these standards meet the requirements of technological processes. Compliance with consumption standards allows you to prevent excessive consumption of stocks for unaccounted production, as well as artificial increase in the cost of production. To find out whether the consumption rates are used correctly, it is necessary to carry out the control launch of raw materials in production.

The identity of the data of synthetic, analytical and primary accounting is confirmed by comparing the documents on write-off of inventories and corresponding registers of accounting.

The internal control of operations on the stocks release to the party should begin with the definition of persons who have authorized these operations, the reasons of occurrence of these operations.

Further it is checked up correctness of correspondence of accounts on expense of stocks on production of production, other activity, sale etc.

All operations associated with the release of inventories to third parties should be checked on a continuous basis by reconciliation of the data contained in the expense documents of the warehouse and payment documents, as well as reconciliation of the quantitative data on the names of stocks under the contracts (agreements) with their quantity recorded in the expenditure documents of the warehouse.

In the course of internal control, it is checked whether the rules for issuing powers of attorney for receiving stocks are observed, whether there are cases of write-off of stocks for the costs of manufacturing products, performing work and providing services without documenting their posting.

Control of gratuitous transfer of inventories consists in checking the correctness of determining their value and the correctness of the correspondence of accounts.

Especially carefully it is necessary to check the operations connected with write-off of spoilage, shortage and devaluation of inventories. The documents on legality, timeliness and completeness of their registration, correctness of application of norms of natural loss as well as the amount of losses and shortages taken into account within and outside the norms of natural loss are checked up.

The next step in the internal control of stocks is to analyze the effectiveness of their use. The purpose of the analysis of efficiency of use of stocks consists in providing the internal controller with the information, allowing to draw reasonable conclusions on possibility to 
increase financial stability and increase efficiency of financial and economic activity at the expense of rational use of resources for the purpose of maintenance of economic safety

The analysis determines the level of stocks, which is necessary for an economic entity to carry out an uninterrupted production process; assesses the feasibility of plans for logistics and analyzes the impact of the supply of stocks on costs and output, identifies deviations of actual indicators that characterize the use of reserves from the standards, identifies internal reserves to reduce material costs, determines the optimal amount of reserves necessary to improve the efficiency of production.

In economic literature the following stages of the analysis of the stocks (fig. 4) are distinguished.

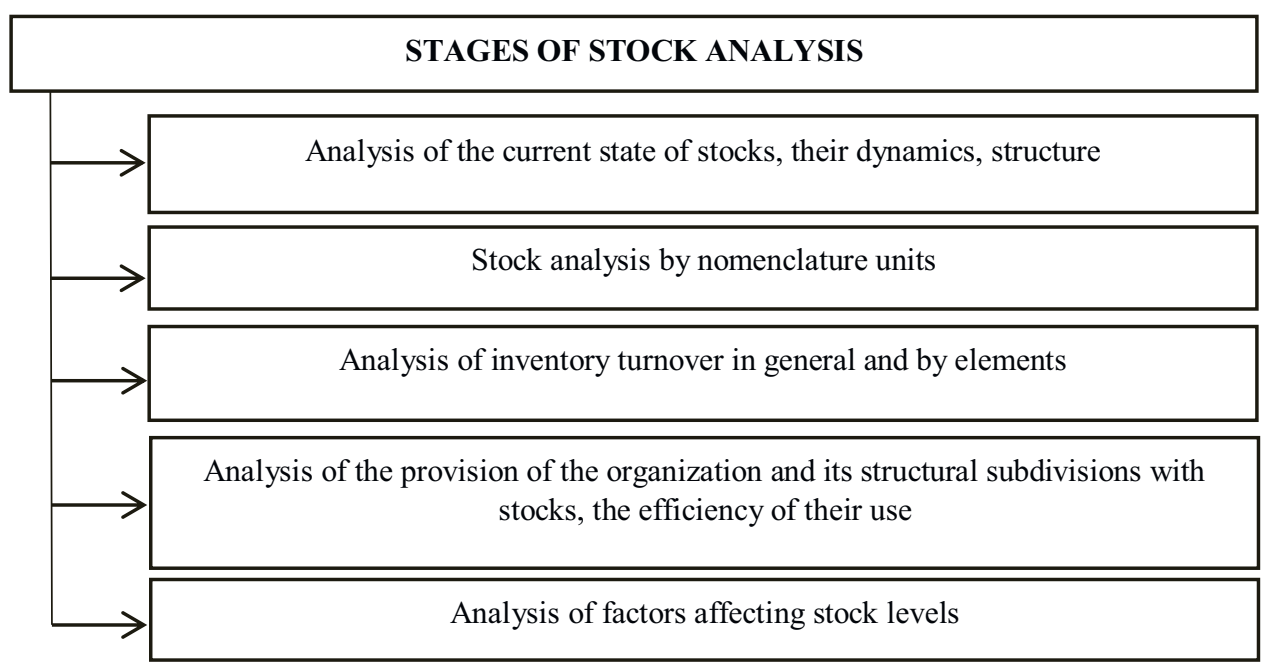

Fig. 4. Stages of stock analysis in internal control.

At the first stage to assess the dynamics, the availability of stocks at the beginning and the end of the reporting period are compared. Analysis of the structure of stocks assumes the calculation of the share of the active part of stocks and the share of certain types of stocks in their total value. The current state is assessed in detail in the dynamics of the elements with a further analysis of stock turnover.

The basis of the analysis of stocks by nomenclature units is the cost of specific stocks and qualitative characteristics of individual elements. In this case special attention is focused on strategically important and small groups of stocks. In addition, at this stage the condition and movement of stocks is analyzed, the effectiveness of the functional unit, which is responsible for a certain type of stock, is evaluated.

Stock turnover analysis is carried out to assess the degree of their usefulness in the production process. The dynamics of turnover is an important criterion for assessing the effectiveness of stock management. Low intensity of turnover of certain inventories relative to the planned values indicates their inefficient use, or the purchase of stocks in excess of the required volume at a sub-optimal price. When analyzing stock turnover, the following indicators are calculated: stock turnover coefficient, shelf life of stocks.

When assessing the availability of an economic entity's stocks, it is necessary to check the reality of the logistics plan. To do this, the norms and standards used in determining the need for stocks are studied. When analyzing the availability of the organization inventory compares the actual amount of existing stocks from internal sources (own production, waste reduction, saving stocks as a result of new technologies) and external sources (receipt from 
suppliers, on account of the warehouse in the share capital, gratuitous receipt) with their planned need.

Analysis of the use of stocks begins with verification of the correctness and validity of their release into production. To determine the need for supplies rates per unit of production multiplied by the number of products to be produced. At agricultural enterprises are not uncommon cases where stocks are used irrationally or there is a shortage. This is due to the fact that some of the stocks coming from their own production do not meet the normative indicators of quality. For example, feed with insufficient nutrients is used up more than high quality feed. In addition, the lack of reserves is often due to insufficient monetary resources for their purchase. In this regard, it is necessary to analyze the use of stocks in production activities.

To characterize the effectiveness of the use of stocks used a system of generalized and private indicators.

To generalizing indicators include such indicators as profit per ruble of material costs, output of materials, material capacity, material equipment, profitability of stocks, the relative economy of stocks.

To assess the efficiency of consumption of certain types of stocks and assess the material intensity of individual products, use private indicators

These indicators are analyzed in the dynamics, the achievement of the planned targets is estimated, the impact of factors on the change in their value is studied, the data of the enterprise is compared to the data of advanced economies, with the average regional indicators.

In the course of the analysis of factors that influence the level of stocks, the factors that influence the volume of stocks are identified, the influence of factors on the volume of production stocks is evaluated, the recommendations that contribute to reducing stocks are developed.

As a result of internal stock control, its results are analyzed and the final document - the act of inspection - is drawn up.

The following information should be included in the act of inspection:

- the subject and object of the inspection;

- the time frame for the audit;

- the audit program, which is agreed with the head of the organization;

- characteristics of the audit objects,

- methods used in the collection and analysis of information;

- description of the data on the compliance of the organization's activities with legal requirements;

- the list of revealed violations and the reasons for them;

- the conclusions obtained as a result of the control measures;

- a list of measures to eliminate the identified violations.

The act of inspection must meet the following requirements:

- objectivity - in the act of inspection the activity of the object of control must be evaluated on the basis of whether the verified facts comply with the requirements of the legislation regulating the controlled activity;

- validity - the act of the audit should contain sufficient factual and legal grounds for making decisions on the results of the control measures;

- consistency - the act of the audit should contain the results of the control measures that cover all aspects of the control object in relation to each other;

- focus on results - conclusions and recommendations contained in the act of the audit should contribute to solving operational and strategic tasks facing the management of the enterprise; 
- compliance - the conclusions and recommendations in the act of the audit should correspond to the content, goals and objectives of the control;

- concreteness - the act of the audit should contain specific conclusions, assessments and suggestions on its results of the control of the key issues of the controlled entity's activity.

The documents confirming the results of the control measures, in particular, explanations of persons responsible for finance and heads of departments, copies of documents which are the basis for business operations, etc., should be attached to the act of the audit.

The act of inspection signed by the controller and responsible persons of the objects of control is submitted to the head of the organization for approval.

\section{Discussion}

An effective management system is the basis for the optimal functioning of an economic entity. In turn, the management system requires information of accounting and nonaccounting nature, provided by management accounting [33]. Internal control is one of the elements of the management accounting system

In the process of internal control receive accurate and up-to-date information about changes in the availability and movement of stocks, which contributes to the adoption of sound, cost-effective management decisions.

It is possible to allocate the following stages of control process as a result of which the information for a control system is formed:

1. Documentation of control activities is characterized by the collection of information about the object of control;

2. Grouping and systematization of information about an object of control;

3. Certain forms of working documents of internal control, used at registration of results of inspection, are formed;

4. Application of the information contained in the working documents of internal control in the analysis of financial and economic activity of the organization.

Documentation of internal control is an important aspect of the audit. Working documents contain information on the planning of the audit, the results of the evaluation of the accounting system and external and internal evidence collected during the audit, for internal control working documents serve as a basis for the preparation of a reliable report on the results of the audit.

At the same time, working documentation allows to evaluate the actions of internal controllers and organize the internal and external quality control of their activities.

The information obtained during internal control and reflected in the working documents may be the basis for making managerial decisions by internal users. Heads of various departments are responsible for the fulfillment of certain tasks and achievement of planned indicators. The division of responsibility between the heads of departments has a hierarchical structure, which is represented by three levels: operational (lower) level, tactical (middle) level, strategic (higher) level. In this regard, the information contained in the working documents of internal control can be classified according to the hierarchical structure:

- detailed operational information, which refers to the current time. Identification of deviations of actual indicators from the planned or normative ones and their analysis, as well as making decisions in the stock management system are of a short-term nature;

- tactical information characterizes the effectiveness of the use of inventory in order to achieve better results. this information serves as the basis for making decisions relating to the supply and procurement, organization of storage and sale of stocks; 
- strategic information is designed to make decisions for the long term with respect to the entire enterprise and determine the directions of its development. Decisions relate to investments in various projects, the development of new markets, budgeting and forecasting.

In this regard, we believe that the information contained in the working documents should be:

- targeted - provided to interested users;

- operative - to be provided in time necessary for making timely management decisions;

- reliable - to record data about real processes and phenomena;

- useful - suitable for analysis and operational control.

To increase informativeness and sufficiency of working documents they can include planned (normative) indicators, similar data of previous periods, indicators on an accrual basis since the beginning of the monitored period. Comparing the controlled indicators with the planned values, you can assess their performance and identify the causes of discrepancies, which may be the result of theft, abuse and violations.

For perfection of the analysis which is carried out during the internal control of stocks we propose to use the forms of working documents of the internal control of movement of stocks (tables 6-8).

Table 6. ICWD «Analysis of stock supplies».

\begin{tabular}{|c|c|c|c|c|c|c|c|c|c|c|c|}
\hline \multirow[b]{3}{*}{ 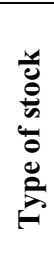 } & \multirow[b]{3}{*}{$\frac{\grave{d}}{0}$} & \multirow{3}{*}{ 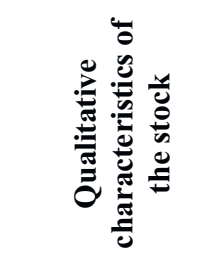 } & \multicolumn{9}{|c|}{ Supply Volume } \\
\hline & & & \multicolumn{3}{|c|}{ plan } & \multicolumn{3}{|c|}{ fact } & \multicolumn{3}{|c|}{ deviations } \\
\hline & & & 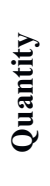 & $\begin{array}{l}\dot{E} \\
\dot{E} \\
\dot{v}\end{array}$ & $\underset{0}{\dot{0}}$ & 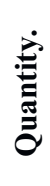 & 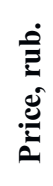 & 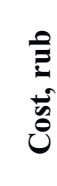 & 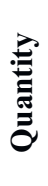 & $\frac{\dot{\theta}}{20}$ & $\begin{array}{l}\frac{0}{0} \\
\vdots \\
\vdots \\
0 \\
0 \\
0\end{array}$ \\
\hline 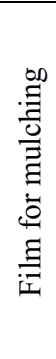 & 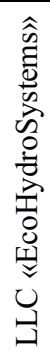 & $\begin{array}{l}\text { Made of special } \\
\text { copolymers, } \\
\text { LDPE (high- } \\
\text { pressure } \\
\text { polyethylene), } \\
1400 \text { mm roll } \\
\text { width, } 500 \mathrm{~m} \\
\text { roll length, } 35 \\
\text { microns, } 1 \mathrm{st} \\
\text { grade }\end{array}$ & $\stackrel{\mathscr{0}}{\bar{O}}$ & $\stackrel{+}{\stackrel{+}{ \pm}}$ & 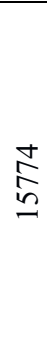 & 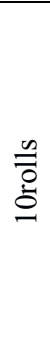 & $\stackrel{\grave{I}}{\unlhd}$ & 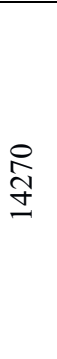 & $\begin{array}{l}\overline{\overline{0}} \\
\stackrel{?}{1}\end{array}$ & T & $\begin{array}{l}\stackrel{+}{0} \\
\stackrel{n}{7}\end{array}$ \\
\hline 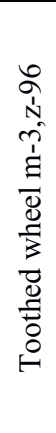 & 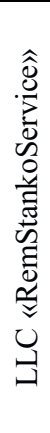 & $\begin{array}{l}\text { Toothed wheel } \\
\text { m-3, z- } \\
96 z a p a s a t e l n a y a \\
\text { part of the } \\
\text { press-granulator } \\
\text { OGM- } 0.8 \text {, } \\
\text { designed for the } \\
\text { production of } \\
\text { high-quality } \\
\text { pellets of feed, } \\
\text { bran, sawdust, } \\
\text { hay, straw, husk }\end{array}$ & 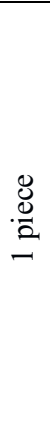 & 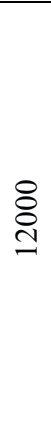 & \&્ర & $\begin{array}{l}0 \\
.0 \\
2\end{array}$ & 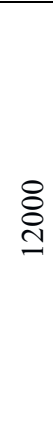 & 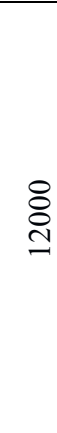 & & ' & \\
\hline
\end{tabular}

In the working document of internal control «Analysis of stock supplies» provides information on the type of purchased inventory, the supplier, the planned and actual volume of supplies, the resulting deviations. Besides, there is a qualitative characteristic of the 
acquired asset. With the help of this document there is an opportunity to control the state of supply discipline, the degree of good faith of suppliers,

Table 7. ICWD «Analysis of inventory movement».

\begin{tabular}{|c|c|c|c|c|c|c|c|c|c|c|c|}
\hline \multirow[b]{2}{*}{ 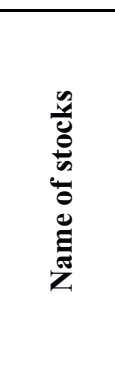 } & \multirow[b]{2}{*}{ 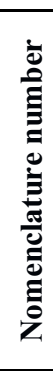 } & \multirow[b]{2}{*}{ 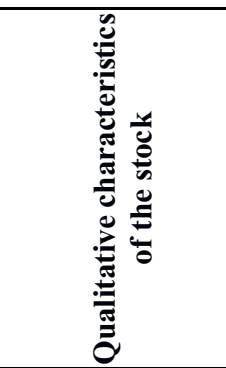 } & \multirow[b]{2}{*}{ 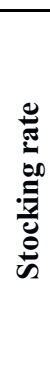 } & \multirow[b]{2}{*}{ 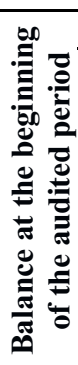 } & \multicolumn{3}{|c|}{ Arrival } & \multicolumn{3}{|c|}{ Consumption } & \multirow[b]{2}{*}{ 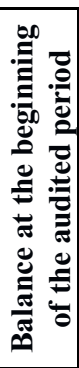 } \\
\hline & & & & & 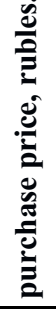 & 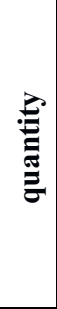 & $\begin{array}{l}\vec{\Xi} \\
\bar{\Xi} \\
\text { E }\end{array}$ & 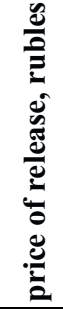 & 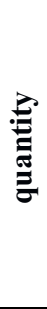 & 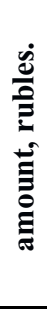 & \\
\hline 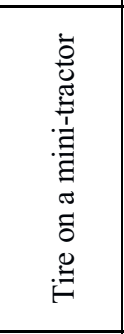 & 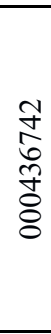 & $\begin{array}{c}\text { Pneumatic tire } \\
\text { Tread:S-247, rim } \\
\text { diameter:8, rim } \\
\text { width:3.75, } \\
\text { outside } \\
\text { diameter:412, } \\
\text { section } \\
\text { width: } 115, \text { ply } \\
\text { size:4PR } \\
\end{array}$ & $\begin{array}{l}\dot{a} \\
\stackrel{\sigma}{\sigma}\end{array}$ & $\begin{array}{l}\mathscr{2} \\
\stackrel{+}{2}\end{array}$ & 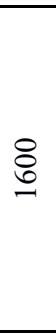 & $\begin{array}{l}0 \\
\text { nn }\end{array}$ & ஓి & $\stackrel{8}{8}$ & $\frac{0}{6}$ & : & 2 \\
\hline 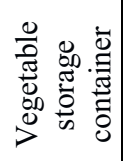 & $\begin{array}{l}2 \\
\frac{1}{8} \\
8 \\
8 \\
8 \\
8\end{array}$ & $\begin{array}{c}\text { Wooden } \\
\text { container } \\
1200 * 1600 \\
\text { H } 1200 \mathrm{~mm}\end{array}$ & $\begin{array}{l}0 \\
2 \\
0\end{array}$ & $\begin{array}{l}\stackrel{0}{2} \\
\text { I }\end{array}$ & $\stackrel{\stackrel{\circ}{7}}{\underset{n}{n}}$ & $\begin{array}{l}0 \\
\stackrel{n}{n}\end{array}$ & $\begin{array}{l}\stackrel{n}{0} \\
\stackrel{0}{n}\end{array}$ & 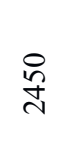 & I & $\frac{\sqrt{6}}{\gamma}$ & \\
\hline
\end{tabular}

Working document of internal control «Analysis of inventory movement» contains information on the name of the stock, the rate of stock, data on the movement of stock in quantitative and value terms for the reporting period, the quality characteristic of the stock, This document allows you to monitor compliance with the actual size of the stocks of important types of raw materials and supplies normative. In addition, based on this document by comparing the income and expenditures, you can identify unnecessary and unclaimed in the production and financial activities of the material resources, as well as establish stocks, which is observed deficit. The deficit of one or another type of material resource can lead to downtime or inefficient replacement of a missing type of material resource, which in turn leads to a decrease in the quality of products, a reduction in production volumes, a decrease in profits. 
Table 8. ICWD «Analysis of the movement of finished products».

\begin{tabular}{|c|c|c|c|c|c|c|c|c|c|c|c|c|c|c|c|}
\hline \multirow{4}{*}{ 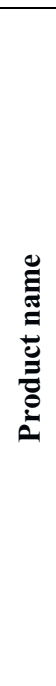 } & \multicolumn{2}{|c|}{$\begin{array}{l}\text { Retrieved } \\
\text { From }\end{array}$} & \multirow{4}{*}{$\stackrel{\grave{D}}{\grave{D}}$} & \multicolumn{8}{|c|}{ Sale } & \multirow{2}{*}{\multicolumn{4}{|c|}{ Deviation }} \\
\hline & \multirow{3}{*}{ 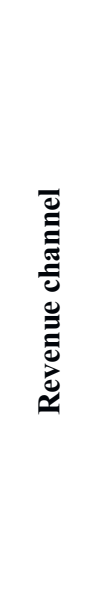 } & \multirow{3}{*}{ 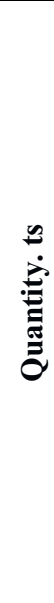 } & & \multicolumn{4}{|c|}{ quantity. cu } & \multicolumn{4}{|c|}{$\begin{array}{l}\text { salesrevenue. } \\
\text { thousandrubles. }\end{array}$} & & & & \\
\hline & & & & \multicolumn{2}{|c|}{ 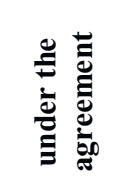 } & \multicolumn{2}{|c|}{ 疍 } & \multicolumn{2}{|c|}{ 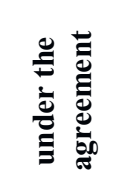 } & \multicolumn{2}{|c|}{ 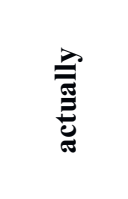 } & \multicolumn{2}{|c|}{ 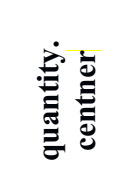 } & \multicolumn{2}{|c|}{ 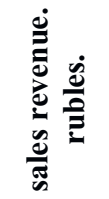 } \\
\hline & & & & 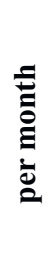 & 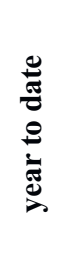 & 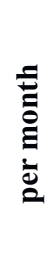 & 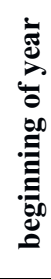 & 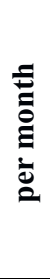 & 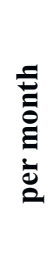 & 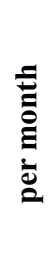 & 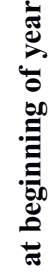 & 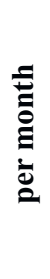 & 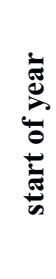 & 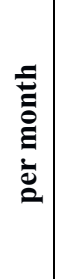 & 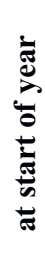 \\
\hline 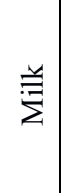 & 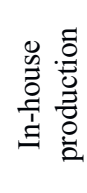 & $\begin{array}{l}n \\
\infty \\
\infty \\
m\end{array}$ & 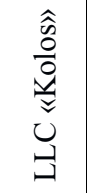 & $\underset{\substack{\infty \\
0}}{\infty}$ & $\begin{array}{l}n \\
\infty \\
\infty \\
\infty\end{array}$ & 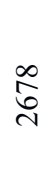 & $\underset{\infty}{\infty}$ & $\frac{\pi}{6}$ & $\frac{a}{\dot{f}}$ & $\frac{1}{6}$ & $\frac{2}{\frac{2}{\sigma}}$ & ' & ' & 1 & ' \\
\hline 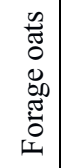 & 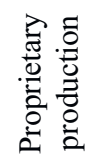 & $\underset{N}{\mathcal{N}}$ & 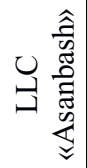 & $\stackrel{\sim}{\ni}$ & $\underset{\infty}{\mathcal{N}}$ & $\stackrel{\sim}{\forall}$ & $\underset{\infty}{\stackrel{Y}{5}}$ & 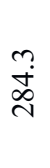 & $\stackrel{\circ}{n}$ & 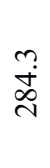 & $\frac{0}{n}$ & 1 & ' & ' & 1 \\
\hline
\end{tabular}

In the working document of internal control « Analysis of the movement of finished products» reflected channel receipt of finished goods, the number of incoming products, the name of the economic entity to whom sold finished products, the number of products sold and proceeds from the sale of the contract and fact, as well as deviations occurred. Using this document you can regulate the production and sale of finished products, to increase profits and reduce the risk of unclaimed production.

\section{Conclusions}

One of the factors of effective development of enterprises is a rational management of stocks. The state of stocks affects the production and financial activities of enterprises and its economic security. To ensure the rational management of inventories, it is necessary to organize their effective control, taking into account the specifics, scale and features of production technology.

In the conditions of development of digital economy the questions connected with control of presence and safety of stocks with the use of information technologies become especially urgent. In this case, internal control of inventories involves checking the right of access to computer programs, checking the frequency of information support and updating the programs used, assess the qualifications of employees of the accounting department and materially responsible persons, checking the frequency of data unloading from the programs used in accounting stocks. 
In order to obtain evidence of the effectiveness of accounting and analytical support for the acquisition, storage, write-off of inventories, we suggest using the ICWD «Test for evaluating the inventory accounting system». This test contains, in our opinion, topical issues that allow us to fully assess the effectiveness of the organization of accounting of stocks at the enterprise.

The ICWD «Questionnaire for checking the condition of storage and safety of stocks » contains questions that allow the internal controller to fully assess the state of the warehouse and the safety of stocks. In addition, the controller has the ability to clarify and concretize the answers to the questions posed in the working document. This, in turn, will allow, based on the results of the audit, to provide the manager with all the information necessary for making effective management decisions.

To increase the informativeness and sufficiency of working documents when analyzing the movement of stocks, we recommend using working documents of internal control containing planned (normative) indicators, similar data of previous periods, indicators on an accrual basis since the beginning of the controlled period. By comparing the monitored indicators with the planned values, it is possible to assess their implementation and identify the causes of discrepancies, which may occur as a result of theft, abuse and irregularities.

\section{References}

1. I. Koshkina, M. Sharamko, Procedia - Social and Behavioral Sciences 214, 858-865 (2015) https://doi.org/10.1016/j.sbspro.2015.11.741

2. Dz. Faizrakhmanov, A. Zakirova, G. Klychova et al, E3S Web of Conferences 91, 06004 (2019) https://doi.org/10.1051/e3sconf/20199106004

3. E. Grigoreva, L. Garifova, Procedia Economics and Finance 24, 266-273 (2015) https://doi.org/10.1016/S2212-5671(15)00658-9

4. A.K. Subaeva, M.M. Nizamutdinov, L.M. Mavlieva, BIO Web of Conferences 17, 00178 (2020)

5. N. Dutta, D. Meierrieks, International Review of Economics \& Finance 73, 114-126 (2021) https://doi.org/10.1016/j.iref.2021.01.002

6. M. Delis, E. Galariotis, J. Monne, Journal of Banking \& Finance 123, 106035 (2021) https://doi.org/10.1016/j.jbankfin.2020.106035

7. K. Chalmers, D. Hay, H. Khlif, Journal of Accounting Literature 42, 80-103 (2019) https://doi.org/10.1016/j.acclit.2018.03.002

8. J. Wang, K. Hooper, Critical Perspectives on Accounting 49, 18-30 (2017) https://doi.org/10.1016/j.cpa.2017.04.003

9. E. Demirakos, The International Journal of Accounting 53, 253-254 (2018) https://doi.org/10.1016/j.intacc.2018.07.001

10. S.F. Schantl, A. Wagenhofer, Journal of Accounting and Public Policy 1, 106803 (2020) https://doi.org/10.1016/j.jaccpubpol.2020.106803

11. G.S. Klychova, A.R. Zakirova, E.R. Kamilova, International Business Management 10, 5254-5260 (2016) DOI: 10.3923/ibm.2016.5254.5260

12. X.-D. Ji, W. Lu, W. Qu, Journal of Contemporary Accounting \& Economics 14, 266287 (2018) https://doi.org/10.1016/j.jcae.2018.07.002

13. G.S. Klychova, B.G. Ziganshin, A.R. Zakirova et al, Journal of Engineering and Applied Sciences 12, 4958-4965 (2017) DOI: 10.3923/jeasci.2017.4958.4965 
14. J.P. Fernandes, Land Use Policy 82, 563-572 (2019) https://doi.org/10.1016/j. landusepol.2018.12.044

15. Q. Wang, J. Wu, N. Zhao, Q. Zhu, Resources, Conservation and Recycling 145, 78-85 (2019) https://doi.org/10.1016/j.resconrec.2019.02.024

16. V.N. Azarskov, L.S. Zhiteckii, K.Yu. Solovchuk et al, IFAC-Papers On Line 50, 10154-10159 (2017) https://doi.org/10.1016/j.ifacol.2017.08.1762

17. W. Dbouk, L. Moussawi-Haidar, M.Y. Jaber, International Journal of Production Economics 230, 107888 (2020) https://doi.org/10.1016/j.ijpe.2020.107888

18. J. Enqvist, M. Graham, J. Nikkinen, Research in International Business and Finance 32, 36-49 https://doi.org/10.1016/j.ribaf.2014.03.005

19. R.P. Boisjoly, Th.E. Conine, M.B. McDonald, Journal of Business Research 108, 1-8 (2020) https://doi.org/10.1016/j.jbusres.2019.09.025

20. A. Zakirova, G. Klychova, G. Ostaev, et al, E3S Web of Conferences 164, 10009 (2020) https://doi.org/10.1051/e3sconf /202016410009

21. M. Roussy, Critical Perspectives on Accounting 24, 550-571 (2013) https://doi.org/10.1016/j.cpa.2013.08.004

22. G. Klychova, A. Zakirova, S. Alibekov, et al, Advances in Intelligent Systems and Computing 1258 AISC, 669-686 (2021) https://doi.org/10.1007/978-3-030-574505_58

23. J. Leontieva, E. Zaugarova, G. Klychova, A. Zakirova, A. Klychova, MATEC Web of Conferences 170, 01087 (2018) doi.org/10.1051/matecconf/201817001087

24. R. Krane, M. Eulerich, Journal of International Accounting, Auditing and Taxation 41, 100353 (2020) https://doi.org/10.1016/j.intaccaudtax.2020.100353

25. Y.-T. Chang, H. Chen, R.K. Cheng, W. Chi, Journal of Contemporary Accounting \& Economics 15, 1-19 (2019) https://doi.org/10.1016/j.jcae.2018.11.002

26. W. Shu, Y. Chen, B. Lin, Y. Chen, China Journal of Accounting Research 11, 407-427 (2018) https://doi.org/10.1016/j.cjar.2018.09.002

27. D.B. Bryan, Advances in Accounting 36, 11-26 https://doi.org/10.1016/j.adiac.2016.09.005

28. A. Zakirova, G. Klychova, R. Nurieva, et al, Advances in Intelligent Systems and Computing 1259 AISC, 98-123 (2021) https://doi.org/10.1007/978-3-030-57453-6_10

29. A. Gross, J. Hoelscher, B.J. Reed, G.E. Sierra, Journal of Accounting Education (2020) https://doi.org/10.1016/j.jaccedu.2020.100679

30. Y. Gao, L. Han, Microprocessors and Microsystems 19, 104036 (2021) https://doi.org/10.1016/j.micpro.2021.104036

31. K.A. Torkura, M.I.H. Sukmana, F. Cheng, Ch. Meinel, Computers \& Security 102, 102124 (2021) https://doi.org/10.1016/j.cose.2020.102124

32. U.M. Ismail, Sh. Islam, Journal of Information Security and Applications 54, 102594 (2020) https://doi.org/10.1016/j.jisa.2020.102594

33. P.J. Steinbart, R.L. Raschke, G. Gal, W.N. Dill, Accounting, Organizations and Society 71, 15-29 (2018) https://doi.org/10.1016/j.aos.2018.04.005

34. A. Zakirova, G. Klychova, K. Mukhamedzyanov et al, Advances in Intelligent Systems and Computing, 1258 AISC, 687-707 (2021) https://doi.org/10.1007/978-3-03057450-5_59 